\title{
Tillage and fertilizer effect on maize and soybean yields in the Guinea savanna zone of Ghana
}

\author{
Samuel Saaka Jeduah Buah ${ }^{*}$, Hashim Ibrahim', Mavis Derigubah², Martin Kuzie², James Vuuro Segtaa ${ }^{3}$, \\ Jules Bayala ${ }^{4}$, Robert Zougmore ${ }^{5}$ and Mathieu Ouedraogo ${ }^{5}$
}

\begin{abstract}
Background: The most limiting factors for sustainable maize production in smallholder farming systems of subSaharan Africa, especially the savanna agro-ecological zone, are erratic rainfall pattern and low soil fertility.

Methods: Research was conducted with smallholder farmers in 2013 and 2014 in two communities in the Upper West Region of Ghana to evaluate the effects of NPK mineral fertilizer (64-38-38 $\mathrm{kg} \mathrm{ha}^{-1} \mathrm{~N}-\mathrm{P}_{2} \mathrm{O}_{5}-\mathrm{K}_{2} \mathrm{O}$, respectively) on growth and yield of maize at Bompari, and $375 \mathrm{~kg} \mathrm{ha}^{-1}$ of YaraLegume ${ }^{\mathrm{TM}}$ fertilizer $(0-18-13 \mathrm{NPK}+3 \mathrm{CaO}+2$ $\mathrm{MgO}+4 \mathrm{~S}$ ) on growth and yield of soybean at Doggoh, under no-tillage (using pre-plant application of glyphosate) and conventional tillage (using hand hoe).

Results: Mean grain yields of both maize and soybean were higher in 2014 than 2013. In both years, no-tillage and conventional tillage had similar effect on soybean plant height, pods per plant and aboveground dry matter production. Averaging over fertilizer treatment, grain yield of no-tillage soybean was 51\% higher when compared with tilled soybean in 2014 only. Mean grain yield of no-tillage maize was 68\% higher than that of tilled maize in 2013 only. Regardless of tillage method, fertilizer application significantly increased maize and soybean grain yields. Application of fertilizer to soybean resulted in 59\% (193 kg ha $\left.{ }^{-1}\right)$ and 54\% (474 kg ha $\left.{ }^{-1}\right)$ increase in grain yields in 2013 and 2014, respectively, over no fertilizer treatment. Mean grain yield of maize was 140 and $252 \%$ higher with fertilizer treatment in 2013 and 2014, respectively. No-till system showed cost savings due to reduced labour mainly for weed control.

Conclusion: The results of these studies showed that no-tillage with fertilizer, whether for maize or soybean, generally resulted in the highest grain yields. No-tillage also gave the highest economic returns. Farmers can get better returns to the money invested in herbicide for producing maize and soybean under no-till than with their traditional practice even on degraded savanna soils with low levels of plant available nutrients.
\end{abstract}

Keywords: Maize, Soybean, No-till, Mineral fertilizer, Economic analysis, Ghana, Rainfall, Soil fertility

\section{Background}

The most limiting factors for sustainable maize (Zea mays L.) production in smallholder farming systems of subSaharan Africa (SSA), especially the savanna agro-ecological zone, are erratic and unpredictable rains and low soil fertility. The major causes of the low soil fertility are

\footnotetext{
*Correspondence: ssbuah@yahoo.com

${ }^{1}$ CSIR-Savanna Agricultural Research Institute (CSIR-SARI), Wa Station, P.O. Box 494, Wa, Ghana

Full list of author information is available at the end of the article
}

low levels of nutrient inputs, continuous cropping, overgrazing, deforestation, and poor soil and water conservation measures [1]. The situation is further aggravated by increased population pressure and limited availability of fertile land. In the past, resource-poor farmers growing food crops in SSA relied on the extensive bush fallow system for maintaining the productivity of their farmlands. This system allowed nitrogen $(\mathrm{N})$ and phosphorus $(\mathrm{P})$, the most limiting nutrients, to be restored. However, with the current pressure on arable land, the practice of using shifting cultivation and/or natural fallows to regenerate 
the productivity of farmlands can no longer be sustained. Given the growing demands for food and feed production in a changing climate, sustainable interventions are critically required to increase maize productivity while conserving the natural resource base and preventing further degradation that has characterized most soils in the zone.

Soybean [Glycine $\max$ (L.) Merr], a grain legume, has recently been introduced to farmers in the savanna zone. Due to their ability to biologically fix $\mathrm{N}$, grain legumes are potential alternative sources of $\mathrm{N}$ to increase cereal productivity in smallholder farming communities $[2,3]$. Maize is now cultivated in the drier traditional sorghum (Sorghum bicolor L.) and millet [Pennisetum typhoides (Burn).Stapf \& C.E. Hubbard] niches, a feat made possible by the development of extra-early and early maturing varieties. Farmers in the Guinea savanna agro-ecological zone are aware of the declining soil fertility problems and the effects of climate change and therefore prefer to adapt cropping systems to alleviate the current production constraints.

In the Guinea savanna zone of Ghana, farmers prepare the land by using hand hoe or by ploughing with tractors or drought animals. However, cultivation with the hand hoe is more common. When the soil is subjected to intensive and repeated tillage, it becomes susceptible to high run-off and soil erosion rates, and soil deterioration. This results in progressive decline in soil productivity and low crop yields [4]. Some of the degraded soils often exhibit a general lack of response to mineral fertilizer addition.

Conservation tillage practices that leave a protective amount of crop residue on the soil surface help to control soil erosion, minimize surface crusting, reduce soil water evaporation and increase the rate of water infiltration. Surface residues maintained with no-tillage also can cause soils to remain cool and wet. Nonetheless, crop residue is often used as a source of fuel-wood and an important dry season livestock feed in the Guinea savanna zone of Ghana. The soil therefore is mostly bare for about six months prior to the cropping season. This is even compounded by the occurrence of indiscriminate annual bush fires in the dry season. Complete residue removal for fodder and fuel, and intensive and excessive tillage can deplete soil organic carbon stocks which often lead to the deterioration of soil fertility and soil water storage capacity, resulting in frequent crop failures. Even where some crop residues are left on the fields, the residues are often grazed freely by livestock during the dry season after harvest of the crops. Hence, their overall contribution to organic $\mathrm{N}$ on fields can be negligible [5].

No-tillage, as an aspect of conservation farming, is actively promoted by international research and development organizations to conserve soils and, by this, ensure food security, biodiversity and water conservation. Conservation tillage practices have the potential to stabilize or increase crop yields over time, but the uptake is very slow [4]. Only a few farmers use some sort of notillage system in the Guinea savanna zone of Ghana [6]. A recent study on the performance of conservation tillage practices on soil degradation in West Africa shows that such practices often, but not always, produce a positive grain yield effect [7]. In addition, maize-based conservation systems have showed significantly higher and more stable grain yield trends compared to conventional tillage systems in several studies [8-11]. Improved crop yields can be translated into increased revenues, but a net gain in revenue is achieved only if the benefits exceed additional cost. Nonetheless, proponents of conservation agriculture practices argue that the economic benefits can only be realized in the medium to long term. Data from two years of on-farm studies support cost savings of conservation agriculture practices due to reduced labour and machinery time despite an increase in agro-chemical usage [12].

Addition of organic sources of plant nutrients, especially manure to build soil organic matter (SOM) and rectify multiple nutrient deficiencies, is one option recommended for rehabilitating degraded soils [13]. However, most smallholder farmers cannot obtain sufficient manure due to low livestock numbers and are therefore unable to maintain critical levels of soil organic carbon required to sustain soil productivity. This therefore calls for identification of complementary options to rehabilitate these degraded soils. In West Africa, mineral fertilizer has been found to increase crop yields substantially $[8,13,14]$. However, fertilizers are costly and even not available in most cases.

The research program on Climate Change, Agriculture and Food Security (CCAFS) of the Consultative Group on International Agricultural Research (CGIAR) is working with two communities in the Upper West Region of Ghana to help smallholder farmers adopt innovative agricultural practices that can help them cope with climate change and enhance food security. CCAFS is scaling out the concept of climate-smart agricultural (CSA) interventions through climate-smart villages (CSVs) in Ghana. The two studies presented in this paper are part of the activities carried out in these CSVs in the Guinea savanna zone of Ghana. The objective of the studies was to evaluate the performance of no-till and conventional tillage for drought-tolerant maize and non-shattering soybean production with or without mineral fertilizers in the Guinea savanna zone of Ghana. The studies aimed to find a more appropriate tillage method to tackle the soil moisture constraints of farmers in the semi-arid areas. 


\section{Methods}

\section{Study area}

Two studies, each consisting of farmer-managed trials, were conducted on farmers' fields during the rainy seasons (May to October) of 2013 and 2014 at Doggoh (latitude $10^{\circ} 32^{\prime} \mathrm{N}$, longitude $2^{\circ} 43^{\prime} \mathrm{W}$ ) in Jirapa district and Bompari (latitude $10^{\circ} 37^{\prime} \mathrm{N}$, longitude $2^{\circ} 54^{\prime} \mathrm{W}$ ) in Lawra district. The two communities are located in the Upper West Region of Ghana which lies within the Guinea Savanna agro-ecological zone. The two communities are in high-risk areas, which will likely suffer most from a changing climate. The area has a mono-modal rainfall pattern of about 5-6 months from May to October with maximum occurrence in August and September. Precipitation figures at the meteorological stations nearest to the communities are presented in Fig. 1. The annual mean precipitation is about $1000 \mathrm{~mm}$. There can be wide variations of moisture shortage and surplus, both within and between seasons. A drought year whose total rain is well below the long-term average may still include periods of excessive rain and flooding, while a high rainfall season may include periods of drought. During the dry season (November to April), the area is under the influence of the dry north-eastern trade winds (Harmattan). Mean annual temperature ranges between 27 and $36{ }^{\circ} \mathrm{C}$.

Soil analyses at the experimental sites are presented in Table 1 . The soils at the two sites are predominantly shallow, sandy in texture with sand contents of 90-98\%, and of low water-holding capacity (Table 1 ). The soils of the

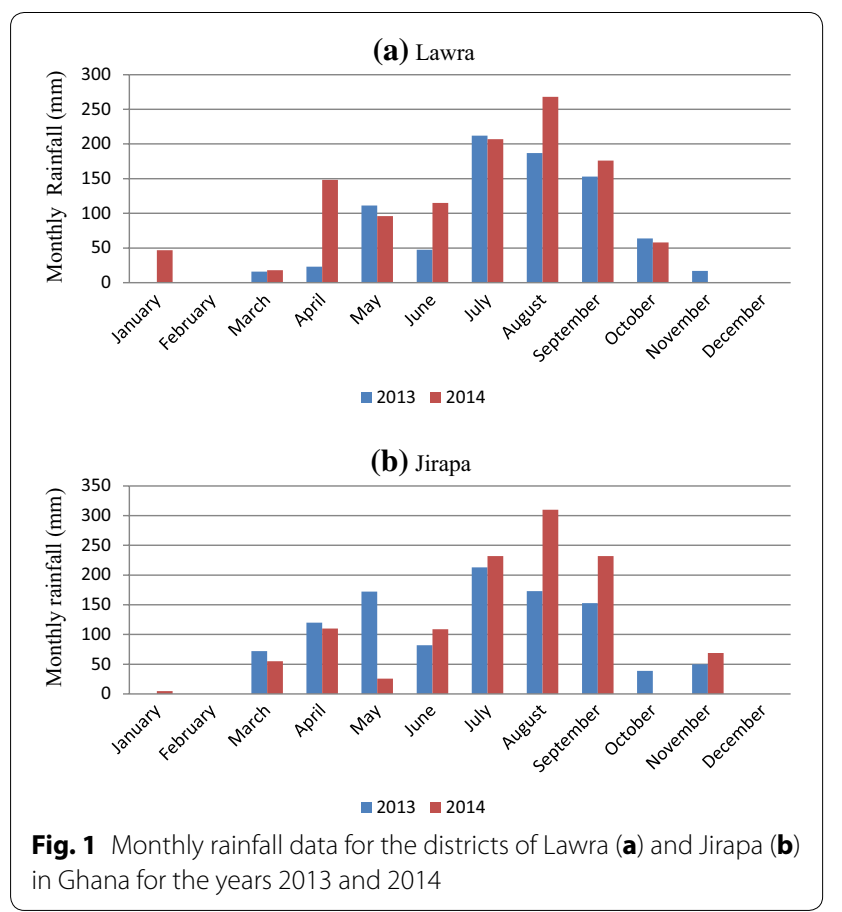

Table 1 Ranges of soil properties for the on-farm trial fields in Doggoh and Bompari communities in the Upper West Region of Ghana

\begin{tabular}{|c|c|c|}
\hline \multirow[t]{2}{*}{ Soil property } & \multicolumn{2}{|l|}{ Location } \\
\hline & Doggoh & Bompari \\
\hline $\mathrm{pH}(1: 2.5)$ & $5.8-6.0$ & $4.9-6.8$ \\
\hline $\mathrm{SOM}\left(\mathrm{g} \mathrm{kg}^{-1}\right)$ & $0.92-1.42$ & $0.53-1.42$ \\
\hline Total $N\left(\mathrm{~g} \mathrm{~kg}^{-1}\right)$ & $0.03-0.04$ & $0.02-0.04$ \\
\hline Extractable P (mg kgkg ${ }^{-1}$ ) & $6.5-7.7$ & $2.7-7.5$ \\
\hline Extractable $\mathrm{K}\left(\mathrm{mg} \mathrm{kg}^{-1}\right)$ & $55.5-79.5$ & $32.9-95.0$ \\
\hline Extractable $\mathrm{Ca}\left(\mathrm{cmol}(+) \mathrm{kg}^{-1}\right)$ & $1.28-2.08$ & $1.28-2.64$ \\
\hline Extractable $\mathrm{Mg}\left(\mathrm{cmol}(+) \mathrm{kg}^{-1}\right)$ & $0.69-0.98$ & $0.55-0.87$ \\
\hline Sand $(\%)$ & $89.6-93.6$ & $93.7-97.8$ \\
\hline Silt (\%) & $1.7-3.6$ & $0.5-2.8$ \\
\hline Clay (\%) & $4.7-6.7$ & $2.1-4.8$ \\
\hline
\end{tabular}

trial fields were highly deficient in $\mathrm{N}, \mathrm{P}$ and $\mathrm{K}$ which is typical for the area where these studies were carried out. The optimum $\mathrm{pH}$ range for maize production is between 6 and 7 [15]. This $\mathrm{pH}$ range is also recommended for maximizing nutrient availability to maize crop. Thus, the soil $\mathrm{pH}$ on most of the fields may not be optimum for maize production as they are acidic. Furthermore, the soils at both sites were low in soil organic matter, total $\mathrm{N}$ and available P. They have weakly developed structure, so the risk of erosion, by wind and water, is high.

Climate change will be especially detrimental to crop production in these areas where soils have been degraded to an extent that they no longer provide adequate waterholding capacity to buffer crops against drought and heat stress. In addition to farm practices, farmers in the two CSVs (Doggoh and Bompari) are also testing climatesmart services, such as tailored weather forecasts to plan planting, harvesting and other activities on the farm. Advisories and weather forecasts are being delivered by mobile phones. As such, the farmers now plan their farming operations better as they now yearn for droughttolerant maize and/or early maturing crop varieties. Farmers were also introduced to non-shattering soybean varieties.

\section{Treatments and experimental design}

The two studies were part of a larger process of participatory action research (PAR) with the Doggoh and Bompari communities that began with farming system characterization and diagnosis, identification of climatesmart agriculture practices, including identification of potential solutions to soil fertility problems, and development of research plans. This process led to farmer participation in the dissemination of research results 
to other farmers. With the approval and support of the members and elders in each community, collaborating farmers were selected to implement the on-farm trials. The purpose of the studies was explained to the collaborating farmers who agreed to implement the trials. The community members were actively involved in project design and development. Constraints identified in the maize and soybean value chains which required technological solutions in the two communities were low rainfall (drought) and poor soils. Prior to planting the trials, farmers received a seasonal forecast and adjusted their plans accordingly. Locally, specific climate information reduces uncertainty and can help farmers to make better use of improved seeds and technologies. Two sets of experiments were conducted for two consecutive years (2013 and 2014). The experimental design in each case was a randomized complete block (RCBD) with farmers as replicates. The two trials implemented in each community were:

\section{Study 1}

Soybean yield response to no-tillage (using pre-plant application of glyphosate) and conventional tillage (using hand hoe) systems with or without mineral fertilizer (YaraLegume $^{\mathrm{TM}}$ : NPK 0-18-13 $+3 \mathrm{CaO}+2 \mathrm{MgO}+4$ S) was evaluated on four (4) farms in each year at Doggoh only. The treatment combinations were: (1) conventional tillage with no mineral fertilizer applied; (2) conventional tillage with mineral fertilizer; (3) no-tillage with no fertilizer and (4) no-tillage with mineral fertilizer. The mineral fertilizer, YaraLegume ${ }^{\mathrm{TM}}$ was applied at a rate of $375 \mathrm{~kg} \mathrm{ha}^{-1}$ to soybean. Conventional tillage using hoe with no fertilizer inputs represented farmers' normal practice for soybean production in the area. The soybean used for this trial was a medium-maturing (105110 days), non-shattering variety (cv Jenguma), which was planted at a spacing of $75 \mathrm{~cm}$ between rows and $5 \mathrm{~cm}$ between plants in a row. The total amount of the fertilizer was applied at seven days after planting (DAP). All fertilizers were applied in a subsurface band about $0.05 \mathrm{~m}$ to the side of the soybean row.

\section{Study 2}

Maize yield response to no-tillage (using pre-plant application of glyphosate) and conventional tillage (using hand hoe) systems with or without mineral fertilizer (64-38-38 $\mathrm{kg} \mathrm{ha}^{-1}$ as $\mathrm{N}, \mathrm{P}_{2} \mathrm{O}_{5}$ and $\mathrm{K}_{2} \mathrm{O}$, respectively) was evaluated on 4 farms each year at Bompari only. The treatments were: (1) conventional tillage with no fertilizer applied representing farmer normal practice; (2) conventional tillage with recommended rate of mineral fertilizer; (3) no-tillage with no fertilizer and (4) no-tillage with recommended rate of mineral fertilizers for maize in this area. Conventional tillage using hoe with no fertilizer inputs represented farmers' normal practice for maize production in the area. The maize variety used this trial was an early maturing (90-95 days) improved droughttolerant, quality protein maize (cv Aburohemaa). Each year, maize was planted at a spacing of $75 \mathrm{~cm}$ between rows and an intra-row spacing of $40 \mathrm{~cm}$ with 2 plants per hill. Three seeds of maize were planted per hole, and after emergence the seedlings were thinned manually to two seedlings per hill to attain a population density of approximately 66,600 plants $^{-1}$, which is the recommended plant population for early maturing maize grown under dry land in this area.

For the maize plots that received mineral fertilizer treatment, the total amount of $\mathrm{P}$ and $\mathrm{K}$ and portion of the $\mathrm{N}\left(38 \mathrm{~kg} \mathrm{~N} \mathrm{ha}^{-1}\right)$ were applied as basal fertilizer in the form of NPK (15:15:15) at seven days after planting (DAP). The $\mathrm{N}$ fertilizer was split applied to maximize $\mathrm{N}$ efficiency. Thus, the remaining $\mathrm{N}$ was top-dressed at 36 DAP in the form of Urea $(46 \% \mathrm{~N})$, when the plants started to grow rapidly and $\mathrm{N}$ demand was high. All fertilizers were applied in a subsurface band about $0.05 \mathrm{~m}$ to the side of the maize row.

The experiments were planted by hand at each location between 15 and 27 July in both years. Prior to planting, composite soil samples from 0 to $15 \mathrm{~cm}$ depth were randomly collected from each experimental field before fertilizer application and analysed for initial soil chemical properties. Standard laboratory procedures were followed in soil samples preparation. Soil samples were mixed, homogenized, air-dried in shade, ground, passed through a 2-mm sieve and analysed for soil texture, $\mathrm{pH}$, organic carbon, total $\mathrm{N}$, available $\mathrm{P}, \mathrm{pH}$ and exchangeable cations $\left(\mathrm{K}^{+}\right.$, $\left.\mathrm{Ca}^{2+}, \mathrm{Mg}^{2+}\right)$ according to standard soil testing procedures [16].

In both studies, the conventional tillage plots were ploughed with hand hoe in June each year before the treatments were imposed. In these studies, no-tillage refers to land preparation through slashing of existing vegetation, allowing for some regrowth and then application of a glyphosate-based systemic herbicide (380 g a.i $\left.\mathrm{L}^{-1}\right)$ prior to planting. Glyphosate ( $N$-phosphonomethyl glycine) was applied to kill existing weeds on notill plots at $3 \mathrm{~L} \mathrm{ha}^{-1}$. The herbicide was applied using a knapsack sprayer calibrated to deliver $150 \mathrm{~L} \mathrm{ha}^{-1}$ of spray solution using low-volume nozzles. Residues from vegetation were left on the soil surface as mulch and maize planted through the mulch. Soybean and maize were planted a week after application of the herbicide. The treatments were not replicated on each farmer's plot. However, in each year, the four farmers in each community who planted the trials represented four replicates. 
Recommended production practices for both maize and soybean were used in both years. At each experimental site, the experimental unit was $100 \mathrm{~m}^{2}$ for both studies. Weeds were removed with hand hoes as needed. The participating farmers determined other management practices, including the timing of planting and weeding operations. No insecticide or fungicide was applied as there was no serious incidence of insect pests or diseases. The experiments for each crop were repeated in the same communities, but on different plots each year.

Maize grain yield was determined by hand-harvesting cobs in the whole plot after physiological maturity and air-dried. Grain yield was calculated based on $80 \%$ shelling percentage and adjusted to $15 \%\left(150 \mathrm{~g} \mathrm{~kg}^{-1}\right)$ water content, with the assumption that the grain weight constitutes $80 \%$ of the cob weight [17]. Other measurements included plant height $(\mathrm{m})$, biomass (aboveground dry matter) yield $\left(\mathrm{kg} \mathrm{ha}^{-1}\right)$ and grain yield $\left(\mathrm{kg} \mathrm{ha}^{-1}\right)$. Plant height was recorded on five randomly selected plants at maturity by measuring the height from the base of the plant to where tassel branching begins. Biomass yields were determined by harvesting the whole plot. Biomass yield was based on samples dried to constant weight at $60{ }^{\circ} \mathrm{C}$. For soybean grain yield determination, pods on plants from the entire experimental unit were handharvested, sun-dried and hand-threshed. Grain yield $\left(\mathrm{kg} \mathrm{ha}^{-1}\right)$ of soybean was adjusted to water content of $130 \mathrm{~g} \mathrm{~kg}^{-1}$. The moisture content of grain samples from each plot was determined using Farmex MT-16 grain moisture tester.

\section{Data analysis}

Combined analysis of variance (ANOVA) across years was performed for each location using the PROC Mixed procedure of Statistical Analysis System (SAS) for Windows Release 9.2 (SAS Institute Inc., Cary, NC). Siteseasons and fields (replicates) were treated as random variables and the fertilizer rates and tillage systems as fixed variables in determining expected mean square and appropriate F-tests in the ANOVA. Main effects and all interactions were considered significant at $P \leq 0.05$. Where the ANOVA showed significant differences of variables between treatments, means were separated using least significant difference (LSD). Pearson's correlation coefficient was used to test for a correlation between grain yield and other variables using PROC CORR of SAS.

\section{Economic analysis}

Economic analysis was performed using the partialbudget procedure to determine the treatment combinations that would give acceptable returns at low risk to farmers [18]. Prevailing farm gate prices for inputs at planting and for outputs at the time the crop was harvested were used for the analysis. All costs and benefits were calculated on a hectare basis in US dollars (US\$ $\mathrm{ha}^{-1}$ ). The concepts used in the partial-budget analysis are defined below:

- Mean grain yield is average yield $\left(\mathrm{kg} \mathrm{ha}^{-1}\right)$ of each treatment in both years;

- The gross benefit per ha is the product of field price of maize or soybean and the mean yield for each treatment;

- The field cost of fertilizer is the product of the quantity required by each treatment per hectare and the field price of fertilizer (i.e. fertilizer retail costs plus the costs of transporting from the point of sale to the farm);

- The cost of fertilizer application is the product of man-days used in applying the fertilizer and the wage rate;

- The field cost of herbicide is the product of the quantity required by each treatment per hectare and the field price of herbicide (i.e. herbicide retail costs plus the costs of application);

- The cost of herbicide application is the product of man-days used in applying the herbicide and the wage rate;

- The total variable cost (TVC) is the sum of field cost of land preparation, fertilizers, herbicide and the costs of fertilizers and herbicide application;

- The net benefit per ha (NB) for each treatment is the difference between the gross benefit and the total variable costs;

The percent marginal rate of return (MRR), which is the increased benefit of an option as a percentage of the increased cost, was used to determine the benefits to farmers. Thus, a MRR of $100 \%$ implies a return of one US dollar on every dollar of expenditure in the given variable input. Thus, MRR of $100 \%$ is chosen as the minimum acceptable value for both maize and soybean in these studies.

In addition to the profitability of a new technology, attention must be paid to its sensitivity to environmental contingencies. This means taking account of factors such as the stability of the yield. However, in these on-farm experiments, scaling down of grain yields was not necessary because the experimental designs were very close to the farmers' practice. It is worthy of note that the input and output prices used in the economic analysis were those prevailing during 2013 and 2014. However, input and product prices are dynamic and subject to change. As such, a recalculation of the partial budget using a set of likely future prices, i.e. sensitivity analysis, is necessary 
to identify treatments that are likely to remain stable and sustain acceptable returns to farmers despite variability in prices [18]. Thus, we assumed a price variation of about $20 \%$ for each crop, which is realistic under the liberal market conditions prevailing in Ghana at the time. Some considerations in projecting prices were increased maize and soybean grain supply due to increased production as a result of the massive initiative by Masara N'Arziki, a non-governmental organization (NGO) which provides financial support in the form of land preparation and inputs (fertilizer and hybrid maize seed) to farmers to produce maize grain for export, and a deteriorating business environment in Ghana, as well as the removal of subsidy on fertilizers. Two other NGOs, Care International-Ghana and MEDA, also support women's groups in the region to produce soybean. Thus, we assumed a $20 \%$ increase in the field price of fertilizers, as well as a $20 \%$ reduction in grain price of each crop.

\section{Results}

\section{Soybean response to tillage and fertilizer}

The effect of fertilizer application on soybean yield varied with the prevailing weather conditions in a particular growing season. Year, tillage and fertilizer treatment had significant effect on soybean grain yield $(P \leq 0.01)$, while also significant year $\times$ tillage $\times$ fertilizer treatment interactions $(P \leq 0.01)$ for plant height, pod number, grain and biomass yield were observed. Therefore, data were not pooled across the two years and are consequently presented by year (Table 2). In both years, there were no significant tillage systems by fertilizer interactions for any parameter measured or calculated, and hence, the main effects of tillage and fertilizer are presented and discussed. In general, precipitation in 2014 was greater and better distributed than in 2013 (Fig. 1). Consequently, soybean grain yield was consistently low during the short rainy season in 2013. Mean soybean grain yield in 2014 was $132 \%$ ( $557 \mathrm{~kg} \mathrm{ha}^{-1}$ ) higher than the yield recorded in 2013. Tillage systems did not significantly influence plant height, pods per plant, grain yield and aboveground dry matter production, when averaged over fertilizer levels in 2013. Although not statistically significant, no-tillage tended to increase mean soybean grain yield by $15 \%$ in 2013. However, in 2014, no-tillage significantly increased soybean grain yield by $51 \%\left(400 \mathrm{~kg} \mathrm{ha}^{-1}\right)$ when compared with conventional tillage. Averaging over tillage systems, added fertilizer resulted in soybean grain yield increases of $59 \%\left(193 \mathrm{~kg} \mathrm{ha}^{-1}\right)$ in 2013 and 54\% (414 $\left.\mathrm{kg} \mathrm{ha}^{-1}\right)$ in 2014, when compared with no fertilizer treatment. Added fertilizer increased biomass production in 2014 only. In 2013, added fertilizer increased plant height and grain yield but pods per plant and biomass production were not significantly affected. In contrast, biomass yield increased significantly by $59 \%$ in 2014 . Pods per plant were also higher for fertilizer treatment in 2014. Grain yield was correlated with pods per plant $(r=0.70)$ and biomass $(r=0.99)$.

\section{Maize response to tillage and fertilizer}

Similar to soybean performance, the effect of fertilizer application on maize grain yield varied with the prevailing weather conditions in 2013 and 2014 growing seasons. Year, tillage and fertilizer treatment had significant effect on grain yield $(P \leq 0.01)$, while significant year tillage $\times$ fertilizer treatment interactions $(P \leq 0.01)$ for grain and biomass yields were also observed. Therefore, data were not pooled across the two years and are consequently presented separately for each year (Table 3). Over the

Table 2 Effect of tillage systems and fertilizer treatments on plant height, pod number, grain and biomass yield of soybean at Doggoh, Jirapa district in 2013 and 2014

\begin{tabular}{|c|c|c|c|c|c|c|c|c|}
\hline \multirow{2}{*}{$\begin{array}{l}\text { Treatment } \\
\text { Tillage }\end{array}$} & \multicolumn{4}{|l|}{2013} & \multicolumn{4}{|l|}{2014} \\
\hline & $\begin{array}{l}\text { Plant height } \\
\text { (cm) }\end{array}$ & $\begin{array}{l}\text { Pods } \\
\text { per plant (no) }\end{array}$ & $\begin{array}{l}\text { Grain yield } \\
\left(\mathrm{kg} \mathrm{ha}^{-1}\right)\end{array}$ & $\begin{array}{l}\text { Biomass yield } \\
\left(\mathrm{kg} \mathrm{ha}^{-1}\right)\end{array}$ & $\begin{array}{l}\text { Plant height } \\
\text { (cm) }\end{array}$ & $\begin{array}{l}\text { Pods } \\
\text { per plant (no) }\end{array}$ & $\begin{array}{l}\text { Grain yield } \\
\left(\mathrm{kg} \mathrm{ha}^{-1}\right)\end{array}$ & $\begin{array}{l}\text { Biomass yield } \\
\left(\mathrm{kg} \mathrm{ha}^{-1}\right)\end{array}$ \\
\hline $\begin{array}{l}\text { Conventional } \\
\text { tillage }\end{array}$ & 32 & 13 & 393 & 3100 & 53 & 20 & 780 & 1153 \\
\hline No-tillage & 30 & 18 & 453 & 2607 & 49 & 19 & 1180 & 1257 \\
\hline LSD (0.05) & NS & NS & NS & NS & NS & NS & 195 & NS \\
\hline \multicolumn{9}{|c|}{ Fertilizer treatment } \\
\hline No fertilizer & 27 & 11 & 327 & 2307 & 1063 & 160 & 773 & 930 \\
\hline $\begin{array}{l}\text { Recom- } \\
\text { mended } \\
\text { fertilizer rate }\end{array}$ & 35 & 20 & 520 & 3400 & 1525 & 188 & 1187 & 1480 \\
\hline $\operatorname{LSD}(0.05)$ & 6 & NS & 122 & NS & NS & 25 & 105 & 378 \\
\hline CV\% & 13.9 & 59.0 & 20.4 & 50.6 & 54.4 & 21.9 & 22.9 & 30.0 \\
\hline
\end{tabular}

NS not significant at the $5 \%$ probability level; recommended fertilizer rate $=25-60-30 \mathrm{~kg} \mathrm{ha}^{-1}$ as N, $\mathrm{P}_{2} \mathrm{O}_{5}$ and $\mathrm{K}_{2} \mathrm{O}$, respectively 
Table 3 Effect of tillage systems and fertilizer treatments on plant height, cob number, grain and biomass yields of maize at Bompari, Lawra district in 2013 and 2014

\begin{tabular}{|c|c|c|c|c|c|c|c|c|}
\hline \multirow{2}{*}{$\begin{array}{l}\text { Treatment } \\
\text { Tillage }\end{array}$} & \multicolumn{4}{|l|}{2013} & \multicolumn{4}{|l|}{2014} \\
\hline & $\begin{array}{l}\text { Plant height } \\
\text { (cm) }\end{array}$ & $\begin{array}{l}\text { Cobs per ha } \\
\text { (no) }\end{array}$ & $\begin{array}{l}\text { Grain yield } \\
\left(\mathrm{kg} \mathrm{ha}^{-1}\right)\end{array}$ & $\begin{array}{l}\text { Biomass yield } \\
\left(\mathrm{kg} \mathrm{ha}^{-1}\right)\end{array}$ & $\begin{array}{l}\text { Plant height } \\
\text { (cm) }\end{array}$ & $\begin{array}{l}\text { Cobs per ha } \\
\text { (no) }\end{array}$ & $\begin{array}{l}\text { Grain yield } \\
\left(\mathrm{kg} \mathrm{ha}^{-1}\right)\end{array}$ & $\begin{array}{l}\text { Biomass yield } \\
\left(\mathrm{kg} \mathrm{ha}^{-1}\right)\end{array}$ \\
\hline $\begin{array}{l}\text { Conventional } \\
\text { tillage }\end{array}$ & 115 & 24,450 & 679 & 947 & 116 & 20,667 & 1387 & 1797 \\
\hline No-tillage & 128 & 25,750 & 1143 & 1844 & 143 & 2700 & 2047 & 2487 \\
\hline Lsd (0.05) & 11 & NS & 430 & NS & 23 & NS & NS & NS \\
\hline \multicolumn{9}{|c|}{ Fertilizer treatment } \\
\hline No fertilizer & 116 & 22,650 & 531 & 1163 & 96 & 16,333 & 760 & 1647 \\
\hline $\begin{array}{l}\text { Recom- } \\
\text { mended } \\
\text { fertilizer rate }\end{array}$ & 127 & 26,590 & 1291 & 1628 & 164 & 31,333 & 2673 & 2627 \\
\hline $\operatorname{LSD}(0.05)$ & 11 & NS & 430 & NS & 23 & 9747 & 875 & 746 \\
\hline CV\% & 6.4 & 16.3 & 33.4 & 49.0 & 12.4 & 28.9 & 36.0 & 24.7 \\
\hline
\end{tabular}

NS not significant at the $5 \%$ probability level; recommended fertilizer rate $=25-60-30 \mathrm{~kg} \mathrm{ha}^{-1}$ as $\mathrm{N}, \mathrm{P}_{2} \mathrm{O}_{5}$ and $\mathrm{K}_{2} \mathrm{O}$, respectively

years, tillage systems by fertilizer interactions were not significant for any maize parameter measured or calculated, and hence, the main effects of tillage and fertilizer are presented and discussed. In general, precipitation in 2014 was greater than in 2013. Hence, maize grain yield was consistently low during the short rainy season in 2013. Maize yields in 2014 were $88 \%\left(808 \mathrm{~kg} \mathrm{ha}^{-1}\right)$ higher than yields in 2013 (Table 3). In 2013, no-tillage significantly increased plant height and grain yield, but biomass yield and cob weight were not affected by tillage systems. Compared with conventional tillage system, no-tillage increased maize grain yield significantly by $68 \%\left(464 \mathrm{~kg} \mathrm{ha}^{-1}\right)$ in 2013. Although not statistically significant, mean grain yield tended to increase by $48 \%\left(660 \mathrm{~kg} \mathrm{ha}^{-1}\right)$ with the use of no-tillage in 2014. In both years, maize grain yields were further increased with added fertilizer, irrespective of tillage system. Compared with no fertilizer treatment, mean grain yields with fertilizer treatment were 143\% $\left(760 \mathrm{~kg} \mathrm{ha}^{-1}\right)$ in 2013 and 252\% (1913 $\left.\mathrm{kg} \mathrm{ha}^{-1}\right)$ in 2014. In addition, added fertilizer significantly increased maize biomass yield (by 60\%), but in 2014 only, when compared with no fertilizer treatment. Maize grain yield was correlated with cobs per plant $(r=0.92)$, biomass $(r=0.64$ and 0.74$)$ and harvest index $(r=0.70)$.

\section{Economic analysis}

The cost of labour for weed control in no-tillage maize and soybean was low compared with conventional tillage systems (Tables 4, 5). For all treatments, net benefits in 2014 were generally higher than those obtained in 2013. The monetary returns were greatest with no-tillage system and least for ploughed tillage. Net benefits for no-tillage system were always higher than those for conventional tillage for both maize and soybean (Tables 4,5 ).
Within each tillage system, monetary returns were greatest when fertilizer was applied, and least for no fertilizer addition, except for soybean in 2013.

For the soybean trials, the marginal rate of return (MRR) between no fertilizer treatment (farmers' practice) and the fertilizer treatment under each tillage system was less than $100 \%$ in both years as a result of low grain yields. Nonetheless, the MRR between no fertilizer treatment and the fertilizer treatment under conventional tillage system for maize was only $28 \%$ in 2013 while it was as high as $320 \%$ in 2014 . Under no-tillage system, MRR between no fertilizer treatment and the fertilizer treatment for maize was 103\% in 2013 and 394\% in 2014 . These values were higher than the minimum acceptable value of $100 \%$. Changing from farmers' traditional practice of no fertilizer addition to maize to added fertilizer gave MRR higher than $100 \%$, irrespective of the tillage system in 2014.

With the sensitivity analysis, partial-budget analysis using the new prices (i.e. $20 \%$ increase in the field price of fertilizers and $20 \%$ reduction in grain price) revealed that in 2014, fertilizer use with conventional tillage and no-till gave high MRR values of 186 and 236\% for maize, respectively (data not shown). However, MRR values were less than 100\% for fertilizer treatments for maize in 2013 and for soybean in both years.

\section{Discussion}

Overall, maize and soybean yield responses to mineral fertilizer were lower in 2013 at all sites than in 2014. This may be due to higher and well-distributed rainfall during the crop growth in 2014 than in 2013, at both locations. Moreover, a prolonged mid-season dry spell in 2013, which coincided with grain fill stages of both maize 
Table 4 Economic analysis of fertilizer treatments and tillage systems effects on soybean at current prices at Doggoh in 2013 and 2014

\begin{tabular}{|c|c|c|c|c|c|c|c|c|}
\hline \multirow[t]{2}{*}{ Variable } & \multicolumn{4}{|l|}{2013} & \multicolumn{4}{|l|}{2014} \\
\hline & $\begin{array}{l}\text { CT without } \\
\text { fertilizer }\end{array}$ & $\begin{array}{l}\text { CT with } \\
\text { fertilizer }\end{array}$ & $\begin{array}{l}\text { NT without } \\
\text { fertilizer }\end{array}$ & $\begin{array}{l}\text { NT with } \\
\text { fertilizer }\end{array}$ & $\begin{array}{l}\text { CT without } \\
\text { fertilizer }\end{array}$ & $\begin{array}{l}\text { CT with } \\
\text { fertilizer }\end{array}$ & $\begin{array}{l}\text { NT without } \\
\text { fertilizer }\end{array}$ & $\begin{array}{l}\text { NT with } \\
\text { fertilizer }\end{array}$ \\
\hline $\begin{array}{l}\text { Output (yield of soybean } \\
\text { in } \mathrm{kg} \mathrm{ha}^{-1} \text { ) }\end{array}$ & 293 & 493 & 366 & 547 & 567 & 993 & 980 & 1380 \\
\hline Grain price (US\$ kg $\left.{ }^{-1}\right)$ & 0.69 & 0.69 & 0.69 & 0.69 & 0.77 & 0.77 & 0.77 & 0.77 \\
\hline Gross return (US\$ ha-1) & 202.07 & 340.00 & 252.41 & 377,24 & 438.97 & 768.77 & 758.71 & 1068.39 \\
\hline Ploughing (US\$ ha ${ }^{-1}$ ) & 51.72 & 51.72 & 0.00 & 0.00 & 48.39 & 48.39 & 0.00 & 0.00 \\
\hline $\begin{array}{l}\text { Herbicide and applica- } \\
\left.\text { tion costs (US\$ ha }{ }^{-1}\right)\end{array}$ & 0.00 & 0.00 & 31.38 & 31.38 & 0.00 & 0.00 & 32.93 & 32.93 \\
\hline $\begin{array}{l}\text { Weed control (labour) } \\
\left(\text { US } \$ \mathrm{ha}^{-1}\right)\end{array}$ & 86.21 & 86.21 & 43.10 & 43.10 & 80.65 & 80.65 & 40.32 & 40.32 \\
\hline $\begin{array}{l}\text { Fertilizer and application } \\
\left.\text { costs (US\$ ha }{ }^{-1}\right)\end{array}$ & 0.00 & 229.31 & 0.00 & 229.31 & 0.00 & 215.96 & 0.00 & 215.96 \\
\hline $\begin{array}{l}\text { Total variable cost (US\$ } \\
\mathrm{ha}^{-1} \text { ) }\end{array}$ & 137.93 & 367.24 & 74.48 & 303.79 & 129.03 & 344.99 & 73.25 & 289.21 \\
\hline Net benefits (US\$ ha ${ }^{-1}$ ) & 64.14 & $(27.24)$ & 177.93 & 73.45 & 309.94 & 425.23 & 686.13 & 781.29 \\
\hline MRR (\%) & & $(40)$ & & (46) & & 53 & & 44 \\
\hline
\end{tabular}

CT conventional tillage, $N T$ no-tillage

Table 5 Economic analysis of fertilizer treatment and tillage system effects on maize at current prices at Bompari in 2013 and 2014

\begin{tabular}{|c|c|c|c|c|c|c|c|c|}
\hline \multirow[t]{2}{*}{ Variable } & \multicolumn{4}{|l|}{2013} & \multicolumn{4}{|l|}{2014} \\
\hline & $\begin{array}{l}\text { CT without } \\
\text { fertilizer }\end{array}$ & $\begin{array}{l}\text { CT with } \\
\text { fertilizer }\end{array}$ & $\begin{array}{l}\text { NT without } \\
\text { fertilizer }\end{array}$ & $\begin{array}{l}\text { NT with } \\
\text { fertilizer }\end{array}$ & $\begin{array}{l}\text { CT without } \\
\text { fertilizer }\end{array}$ & $\begin{array}{l}\text { CT with } \\
\text { fertilizer }\end{array}$ & $\begin{array}{l}\text { NT without } \\
\text { fertilizer }\end{array}$ & $\begin{array}{l}\text { NT with } \\
\text { fertilizer }\end{array}$ \\
\hline $\begin{array}{l}\text { Output (grain yield of maize } \\
\text { in } \mathrm{kg} \mathrm{ha}^{-1} \text { ) }\end{array}$ & 384 & 973 & 677 & 1608 & 507 & 2267 & 1013 & 3080 \\
\hline Grain price (US\$ kg-1) & 0.41 & 0.41 & 0.41 & 0.41 & 0.39 & 0.39 & 0.39 & 0.39 \\
\hline Gross return (US\$ ha ${ }^{-1}$ ) & 158.90 & 402.62 & 280.14 & 665.38 & 196.26 & 877.55 & 392.13 & 1192.26 \\
\hline Ploughing (US\$ ha ${ }^{-1}$ ) & 51.72 & 51.72 & 0.00 & 0.00 & 56.45 & 56.45 & 0.00 & 0.00 \\
\hline $\begin{array}{l}\text { Herbicide and application } \\
\text { costs (US\$ ha }{ }^{-1} \text { ) }\end{array}$ & 0.00 & 0.00 & 31.38 & 31.38 & 0.00 & 0.00 & 32.26 & 32.26 \\
\hline $\begin{array}{l}\text { Weed control (labour) (US\$ } \\
\text { ha }{ }^{-1} \text { ) }\end{array}$ & 86.21 & 86.21 & 43.21 & 43.21 & 80.65 & 80.65 & 40.32 & 40.32 \\
\hline $\begin{array}{l}\text { Fertilizer and application } \\
\left.\text { costs (US\$ ha }{ }^{-1}\right)\end{array}$ & 0.00 & 190.52 & 0.00 & 190.52 & 0.00 & 162.10 & 0.00 & 162.10 \\
\hline Total variable cost (US\$ ha-1) & 137.93 & 328.45 & 74.48 & 265.00 & 137.10 & 299.19 & 72.58 & 234.68 \\
\hline Net benefits (US\$ ha ${ }^{-1}$ ) & 20.97 & 74.17 & 205.66 & 400.38 & 59.16 & 578.35 & 319.55 & 957.58 \\
\hline MRR (\%) & & 28 & & 103 & & 320 & & 394 \\
\hline
\end{tabular}

CT conventional tillage, $N T$ no-tillage

and soybean, may have reduced grain yield production. The lack of significant interaction between tillage system and fertilizer treatment suggest that, on average, crop response to fertilizer was not affected by tillage systems for all traits measured or calculated for maize and soybean. There were significant increases in soybean and maize grain yields with the no-tillage treatment where early weed growth was controlled with glyphosate application rather than by ploughing in 2014 for soybean and 2013 for maize. Although not statistically significant, mean grain yield of both crops tended to increase with the use of no-tillage the other year. For soybean, averaging over fertilizer treatment, no-tillage plots tended to increase mean grain yield by $15 \%$ in 2013 and increased it by $51 \%$ in 2014 when compared with conventional tillage. Similarly, although not always significant, no-tillage 
plots recorded greater maize yields (48-68\%) over conventional tillage system in both years.

No-tillage is a potentially profitable option for maize and soybean production in the Guinea savanna zone of Ghana. The yield increase with no-tillage was likely due to better weed control and water conservation compared with conventional tillage $[3,10]$. Water conservation was probably improved with no-tillage, especially as significant soil water was probably lost with ploughed tillage and the extra weeding. Farmers weeded only once with no-tillage, as compared to twice with conventional tillage, and achieved better weed control. Labour is scarce and costly during major weeding times, and farmers give priority to weeding cash crops, resulting in late and inadequate weed control in maize and soybean. Any delay in field preparation results in delayed planting, which may result in reduced yield. The greater yield in no-tillage plots compared with conventional tillage is consistent with previous results $[8,9,11]$.

Grain yields of maize and soybean were further increased with fertilizer application, regardless of tillage system. Averaging over tillage systems, fertilizer application resulted in 60 and $66 \%$ increases in soybean grain yield in 2013 and 2014, respectively. Also, fertilizer application increased maize grain yield by 140 and $252 \%$ in 2013 and 2014, respectively. The greater grain yields of both maize and soybean with fertilizer application compared with no fertilizer input are consistent with previous results $[8,10,14,19]$. Indeed, poor kernel formation, increased abortion and ultimately lower grain yield under $\mathrm{N}$ stress have been reported widely $[10,19]$.

Although maize and soybean yields tended to be lower with the conventional than with the no-tillage systems, the input cost of conventional tillage system, on average, was US $\$ 58-$ US $\$ 73$ more than for the no-tillage system for soybean production and US\$18-US\$65 more for maize production. The cost saving associated with no-tillage is consistent with results of Ribera et al. [12], whose data from two years of on-farm studies on conservation agricultural practices showed cost savings due to reduced labour and machinery time, despite an increase in agro-chemical usage, that also calls for sensitizing and training of farmers on safe and efficient use of agrochemicals. The monetary returns were greatest with notillage and least for conventional tillage system. The cost of labour for weed control in no-tillage maize and soybean was lower compared to conventional tillage systems because the frequency of weeding on no-tillage plots was reduced to one weeding as against two weedings for the conventional tillage system. It has been reported that chemical weed control is a cheaper and more effective option [20], which improves crop yields and grain quality [21]. However, overuse of herbicides may have adverse effects on beneficial soil microorganisms as well as detrimental long-term effects on the environment. The reliance on glyphosate with the same mode of action for extended period can contribute to weed shifts and the selection of biotypes with resistance to glyphosate. These glyphosate-resistant weeds survive application of glyphosate and reproduce to increase their numbers in a population. To prevent weeds from growing and to keep glyphosate-resistant weeds under control, it is critical to integrate as many weed management strategies as possible into a weed management plan.

No-tillage, whether for maize or soybean, has shown advantage in yield and economic returns at the two sites, even after just two years of on-farm studies. Given the labour-intensive nature of hand weeding and the costs and human drudgery associated with it, it seems no-tillage has the edge in this area. Thus, the additional costs for tillage operations, in addition to other input costs, make no-tillage a better option for maize and soybean in this area. In addition to the economic and grain yield advantages for maize and soybean production, there is also significant environmental benefits associated with no-tillage in terms of improving soil organic matter, soil quality and water quality. Also, there is a lower potential loss of organic matter through soil erosion. In a no-tillage system, residue can decompose slowly and release nutrients more efficiently into the soil system for crop use. Additionally, retention of crop residue protects the soil from direct impact of raindrops and sunlight, while the minimal soil disturbance enhances soil biological activities as well as soil air, and water movement. Nevertheless, due to the occurrence of indiscriminate annual bush fires in the dry season in the savanna zone, the soil surface is always devoid of vegetation for about six months prior to the cropping season. Additionally, the crop residues left on the fields by farmers are often grazed by livestock during the dry season given that the farmers' fields are not fenced or protected from free roaming animals. This poses serious constraints to conservation agricultural practices in this area, as it is almost impossible to maintain a permanent soil cover. Moreover, the overall contribution of crop residue to organic carbon on such bare soils can be negligible [5].

The application of fertilizer to both maize and soybean resulted in significant grain yield increases relative to the grain yields following no fertilizer application. Although the use of fertilizer means a cash expense to the farmer, the results of the economic analysis showed that fertilizer use led to higher net benefits for maize in both years and for soybean in 2014 in the Guinea savanna zone of Ghana. However, the MRR for fertilizer treatment was less than $100 \%$ in both years for soybean as a result of low grain yields. Moreover, the results of the sensitivity 
analysis showed that with a $20 \%$ increase in the field price of fertilizers and a $20 \%$ reduction in grain price, MRR values would have been less than $100 \%$ for fertilizer treatments for maize in 2013 and for soybean in both years. Thus, fertilizer application does not seem to be profitable every year, especially in soybean. Nevertheless, the use of no-tillage system appears to be a promising CSA practices that could be widely used by smallholder farmers to improve soil structure, increase soil carbon sequestration, prevent soil erosion, maintain food production and secure farmers' livelihoods [22], while contributing to ecosystem services. Emissions from exposed soil surface may be reduced under no-tillage system when compared with conventional tillage system. In order to reduce the risk associated with fertilizer use under erratic rainfall conditions, options such as no-tillage and integrated use of organic and mineral sources of plant nutrients in response to soil moisture conditions may be beneficial to smallholder farmers.

\section{Conclusions}

In this study, the replacement of ploughing with a single glyphosate application was found to be a profitable means of increasing soybean and maize grain yields. Mineral fertilizer application also increased grain yields of droughttolerant maize and soybean in both bad and good rainfall years. Additionally, the application of mineral fertilizer on degraded savanna soils having low levels of plant available nutrients led to higher net benefits in both years in maize and in 2014 in soybean, irrespective of tillage system. Notillage option resulted in significantly higher financial benefit than the farmers' practice. We conclude that notillage, whether for maize or soybean, will likely increase grain yield and economic returns. Therefore, farmers in the Guinea savanna zone can get better returns to the money invested in herbicide for producing maize and soybean under no-tillage than with their traditional practice of hand hoeing. However, they should be more cautious with fertilizer input, whose marginal rate of return is not always positive, especially with soybean, although grain yield is increased. This is particularly important during drier years. To enhance the adoption of no-tillage, there is the need to develop appropriate farm tools or adapt existing ones, like the use of cover crops and crop rotation to sustain soil cover. Extension officers working in the target areas should conduct and effectively use demonstrations to inform farmers of the benefits of integrated soil management practices as part of climate change adaptation. The participating farmers, who were involved from the characterization and diagnosis exercises through the implementation of trials and assessment of the results, are a potential resource for an organized farmer-to-farmer information sharing. Longer-term on-station research is needed to determine the sustainability of no-tillage to soil fertility management on degraded Guinea savanna soils.

\begin{abstract}
Abbreviations
CCAFS: Climate Change, Agriculture and Food Security; CGIAR: Consultative Group on International Agricultural Research; CSA: climate-smart agriculture; CSIR: Council for Scientific and Industrial Research; CSV: climate-smart village; CT: conventional tillage; DAP: days after planting; ICRAF: World Agroforestry Centre; ICRISAT: International Crops Research Institute for the Semi-Arid Tropics; MoFA: Ministry of Food and Agriculture; MEDA: Mennonite Economic Development Associates; MRR: marginal rate of return; NB: net benefits; NGO: non-governmental organization; NPK: nitrogen, phosphorus and potassium fertilizer; NT: no-tillage; SARI: Savanna Agricultural Research Institute; TCV: total variable costs.
\end{abstract}

\begin{abstract}
Authors' contributions
SSJB was involved in the conception of the research idea, design of the experiments, data analysis and also drafted the paper. HI, MD, MK and JVS were involved in the design of the experiments and data collection. JB provided guidance, corrections, supervision to the entire research and critically reviewed the manuscript. RZ and $M O$ read, reviewed and amended the manuscript. All authors read and approved the final manuscript.
\end{abstract}

\section{Author details}

${ }^{1}$ CSIR-Savanna Agricultural Research Institute (CSIR-SARI), Wa Station, P.O. Box 494, Wa, Ghana. ${ }^{2}$ Ministry of Food and Agriculture (MoFA), Jirapa, Jirapa District, Ghana. ${ }^{3}$ Ministry of Food and Agriculture (MoFA), Lawra, Lawra

District, Ghana. ${ }^{4}$ World Agroforestry Centre (ICRAF), West and Central Africa Regional Office - Sahel Node, BP E5118 Bamako, Mali. ${ }^{5}$ The CGIAR Research Program on Climate Change Agriculture and Food Security (CCAFS)/ICRISAT West and Central Africa Regional Office, BP 320 Bamako, Mali.

\section{Acknowledgements}

This work was implemented as part of the CGIAR Research Program on Climate Change, Agriculture and Food Security (CCAFS), a strategic partnership of CGIAR and Future Earth, led by the International Center for Tropical Agriculture (CIAT). We acknowledge the CGIAR Fund Council, Australia (ACIAR), European Union, International Fund for Agricultural Development (IFAD), Ireland, New Zealand, Netherlands, Switzerland, USAID, UK and Thailand for funding to CCAFS. The authors wish to thank the staff of MoFA in Lawra and Jirapa districts for their support in organizing community members for the project activities. We duly appreciate the efforts of CCAFS collaborating farmers who took time off their farms and cooperated with us to make the PAR successful. We acknowledge the role played by the late Mr. Linus Kabo-bah in mobilizing the community members for project work.

\section{Competing interests}

The authors declare that they have no competing interests.

\section{Availability of supporting data}

The data sets used and analysed during the current study are available to readers as in the manuscript. Any other relevant data sets related to the current study are available from the corresponding author on reasonable request.

\section{Ethics approval and consent to participate}

The present study was approved by CSIR-SARI where the first author works. CSIR-SARI has the mandate to generate scientific knowledge, appropriate technological innovations and decision support tools to increase food and fibre crop production in northern Ghana based on a sustainable production system which maintains and/or increases soil fertility. Informed consent was obtained from all participants included in the study. Moreover, the research will not publish any data in a way that enables others to link specific information to the farmers. There is no risk for the farmers to face negative consequences due to their participation in the study.

\section{Funding}

This work was funded by the CGIAR Research Program on Climate Change, Agriculture and Food Security (CCAFS), which is a strategic partnership of the CGIAR and Future Earth. The CCAFS Program is carried out with funding by 
CGIAR Fund Donors, the Canadian International Development Agency (CIDA), the Danish International Development Agency (DANIDA) and the European Union (EU), with technical support from the International Fund for Agricultural Development (IFAD)

Received: 13 April 2016 Accepted: 28 January 2017

Published online: 10 June 2017

\section{References}

1. Tittonell P, Giller KE. When yield gaps are poverty traps: the paradigm of ecological intensification in African smallholder agriculture. Field Crops Res. 2013;143:76-90.

2. Mapfumo P, Mtambanengwe F, Giller KE, Mpepereki S. Tapping indigenous herbaceous legumes for soil fertility management by resource poor farmers in Zimbabwe. Agric Ecosyst Environ. 2005;109:221-33.

3. Nezomba H, Tauro TP, Mtambanengwe F, Mapfumo P. Indigenous legume fallows (indifallows) as an alternative soil fertility resource in smallholder maize cropping systems. Field Crops Res. 2010;115:149-57.

4. Giller KE, Witter E, Corbeels M, Tittonell P. Conservation agriculture and smallholder farming in Africa: the heretics'view. Field Crops Res. 2009; 114(1):23-34.

5. Baudron F, Tittonell P, Corbeels M, Letourmy P, Giller KE. Comparative performance of conservation agriculture and current smallholder farming practices in semi-arid Zimbabwe. Field Crops Res. 2012;132:117-28.

6. Peterson CA. Local-level appraisal of benefits and barriers affecting adoption of climate-smart agricultural practices: Ghana. Technical report for the CGIAR Research Program on Climate Change, Agriculture and Food Security (CCAFS). 2014.

7. Bayala J, Kalinganire A, Tchoundjeu Z, Sinclair F, Garrity D. Conservation agriculture with trees in the West African Sahel-a review. ICRAF occasional paper no 14 World Agroforestry Centre, Nairobi. 2011.

8. Aflakpui GKS, Vyn TJ, Hall MR, Anderson GW, Swanton CJ. Effect of tillage on nitrogen response in corn (Zea mays L.) after established alfalfa. Can J Plant Sci. 1993;73:73-81.
9. Buah SSJ, Polito TA, Killorn R. No-tillage corn response to placement of fertilizer nitrogen, phosphorus, and potassium. Commun Soil Sci Plant Anal. 2000;31:3121-33.

10. Ngwira AR, Aune JB, Mkwinda S. On-farm evaluation of yield and economic benefit of short term maize legume intercropping systems under conservation agriculture in Malawi. Field Crops Res. 2012;132:149-57.

11. Thierfelder C, Chisui JL, Gama M, Cheesman S, Jere ZD, Trent Bunderson W, et al. Maize-based conservation agriculture systems in Malawi: longterm trends in productivity. Field Crops Res. 2013;142:47-57.

12. Ribera LA, Hons F, Richardson JW. An economic comparison between conventional and no-tillage farming systems in Burleson County, Texas. Agron J. 2004;96(2):415-24.

13. Bationo A, Kihara J, Vanlauwe B, Waswa B, Kimetu J. Soil organic carbon dynamics, functions and management in West African agro-ecosystems. Agric Syst. 2007:94:13-25.

14. Buah SSJ, Abatania LN, Aflakpui GKS. Quality protein maize response to nitrogen rate and plant density in the Guinea Savanna zone of Ghana. West Afr J Appl Ecol. 2010;16:9-21.

15. Purseglove JW. Tropical crops. Monocotyledons. Harlow: Longman Science and Technical; 1988.

16. CIMMYT. From agronomic data to farmer recommendations: An economics training manual. Completely revised edition. El Batan, Mexico: CIMMYT. 1988

17. Chikoye D, Ellis-Jones J, Kormawa P, Udensi UE, Ibana SE, Avav T. Options for cogongrass (Imperata cylindrica) control in yam (Dioscorea rotundata) and cassava (Manihot esculenta). Weed Technol. 2006;20:784-92.

18. Li R, Guidong Z, Yumei Z, Zhanzhi X. Damage loss and control technology of weeds in cowpea field. Weed Sci. 2004;2:25-6.

19. Andrade $\mathrm{FH}$, Ortegiu ME, Vega C. Intercepted radiation at flowering and kernel number in Maize. Agron J. 2000;92:92-7.

20. Chikoye D, Schulz S, Ekeleme F. Evaluation of integrated weed management practices in maize in northern Nigeria. Crop Prot. 2004;23:895-900.

21. Schnelle MA, Hensley DL. Effects of pesticides upon nitrogen fixation and nodulation by dry bean. Pest Sci. 1990;28:83-8.

22. Ekboir J, Boa K, Dankyi AA. Impact of No-Till Technologies in Ghana. International Maize and Wheat Improvement Center (CIMMYT). 2002.

\section{Submit your next manuscript to BioMed Central and we will help you at every step:}

- We accept pre-submission inquiries

- Our selector tool helps you to find the most relevant journal

- We provide round the clock customer support

- Convenient online submission

- Thorough peer review

- Inclusion in PubMed and all major indexing services

- Maximum visibility for your research

Submit your manuscript at www.biomedcentral.com/submit
O Biomed Central 